\title{
UPAYA PENGELOLA TAMAN BACAAN MASYARAKAT DALAM MEMPERKUAT MINAT MEMBACA \\ (Studi Kasus TBM Silayung Desa Ciburuy Kecamatan Padalarang)
}

\author{
${ }^{1}$ Rini Rahayu, ${ }^{2}$ Novi Widiastuti \\ 1,2 IKIP Siliwangi \\ 1rinirahayu150@gmail.com, 2noviw9@gmail.com
}

\begin{abstract}
ABSTRAK
Penelitan ini dilatarbelakangi oleh adanya permasalahan yang ditemukan di TBM Silayung yaitu rasio antara jumlah penduduk dengan pengunjung perpustakaan atau pembaca harusnya bisa mencapai angka satu berbanding sepuluh orang per hari. Sementara rasio untuk di Jawa Barat pada saat ini masih berada pada kisaran satu berbanding puluhan ribu. Tujuan dari penelitian ini yaitu (1) Untuk mengetahui proses pengelola TBM Silayung dalam menumbuhkan budaya membaca. (2) Untuk mengetahui strategi pengelola TBM Silayung dalam menumbuhkan budaya membaca. (3) Untuk mengetahui respon pembaca tersebut terhadap pengelolaan TBM Silayung. Teori yang digunakan didalam penelitian ini diantaranya konsep TBM, konsep membaca, konsep pengelolaan dan konsep PLS. Metode yang digunakan menggunakan pendekatan deskriptif kualitatif dan dengan metode kualitatif. Teknik pengumpulan data menggunakan wawancara dan observasi. Lokasi penelitian di TBM Silayung Desa Ciburuy, yang menjadi responden dalam penelitian ini pengelola, sekertaris TBM, dan lima orang perwakilan dari pengunjung TBM. Berdasarkan hasil penelitian bahwa TBM Silayung sudah berupaya menjalankan TBM sesuai dengan perannya. Namun masih perlu ditingkatkan kembali dalam bentuk program-program yang kreatif dan menarik
\end{abstract}

Kata Kunci : Budaya Membaca, Pengelolaan TBM.

\section{A. PENDAHULUAN}

Gemar membaca seharusnya sudah dilakukan sejak dini dan menjadi warna yang melekat dikalangan masyarakat serta menghiasi aktivitas keseharian. Banyak ilmu pengetahuan dan informasi yang didapat dari gemar membaca. Sebagaimana di ketahui kemiskinan menjadi salah satu faktor masih rendahnya tingkat pendidikan masyarakat Indonesia masih rendah sehingga masyarakat Indonesia masih kesulitan memperoleh pekerjaan yang layak. Subekti Makdriani (Tribunjateng.Com : 2017) memaparkan bahwa berdasarkan studi Most Littered Nation In the World 2016 minat baca di Indonesia menduduki peringkat 60 dari 61 negara. Rendahnya minat baca disebabkan beberapa faktor satu diantaranya budaya masyarakat Indonesia yang masih didominasi budaya tutur.

Untuk minat membaca di Jawa Barat yang daerah - daerahnya sudah banyak berkembang dan maju, jumlah penduduk yang suka berkunjung ke perpustakaan masih rendah. Seperti data yang dikeluarkan oleh Kepala Badan Perpustakaan Daerah Enny 
Heryani Ratnasari Soebari (www.pikiran-rakyat.com) bahwa rasio antara jumlah penduduk dengan pengunjung perpustakaan atau pembaca harusnya bisa mencapai angka 1 berbanding 10 orang per hari. Sementara rasio tersebut di Jawa Barat saja saat ini masih berada pada kisaran satu berbanding puluhan ribu. Dengan rasio $1: 10$, Jawa Barat yang kini berpenduduk sekitar 44 juta jiwa, harusnya 4,4 juta orang per hari berkunjung ke perpustakaan. Kenyataannya, masyarakat di Jawa Barat untuk berkunjung ke perpustakaan sekarang baru mencapai rata-rata sekitar 700 orang per hari.

Dalam pasal 3 UU no. 43 tahun 2007 menyebutkan bahwa "Perpustakaan berfungsi sebagai wahana pendidikan, penelitian, pelestarian, informasi dan rekreasi untuk meningkatkan kecerdasan dan kebudayaan bangsa". Pada pasal tersebut sangat jelas sekali, bahwa dengan pengelolaan yang baik sebuah perpustakaan dapat digunakan sebagi tempat mendapatkan informasi, wawasan yang sebelumnya atau belum didapatkan di bangku pendidikan, sebagai tempat penelitian dan pelestarian, perpustakaan dapat menjadi tempat untuk melestarikan hasil budaya manusia.

Walaupun perpustakaan memliki peran penting dan strategis sebagai patner dalam mendukung tujuan pendidikan nasional, yaitu mencerdaskan kehidupan bangsa, namun pada kenyataannya pemberian bantuan untuk perkembangan perpustakaan masih sangat memperhatinkan. Berdasarkan data perpustakaan nasional pada tahun 2017 yaitu hampir 82.505 desa yang ada di Indonesia, baru 21.467 desa yang baru mempunyai perpustakaan.

Taman bacaan dimulai pada tahun 1950 dengan program Taman Pustaka Rakyat (TPR), kemudian diperbaharui pada tahun 1992/1993 dengan program kegiatan TBM. Dengan harap dapat mewujudkan masyarakat gemar belajar (learning society) yang indikatornya yaitu masyarakat gemar membaca (reading society). Taman Bacaan Masyarakat (TBM) merupakan lembaga yang menyelenggarakan pengembangan budaya baca dan minat baca masyarakat, dengan menyediakan fasilitas bahan bacaan kepada masyarakat, dan juga berfungsi sebagai sumber informasi bagi masyarakat di sekitar TBM, selain itu TBM juga dapat berfungsi sebagai lembaga pengembangan masyarakat.

TBM dapat berdiri sendiri menjadi lembaga yang mandiri, atau menginduk pada lembaga utamanya seperti PKBM, Yayasan, dan lain-lain. (Direktorat Jenderal pendidikan Anak Usia Dini dan pendidikan Masyarakat, 2016:1) Peraturan Menteri Pendidikan dan Kebudayaan Nomor 81 Tahun 2013 tentang Pendirian Satuan Pendidikan Nonformal, pasal 1, angka 8 menyatakan bahwa Program Pendidikan Nonformal adalah layanan pendidikan yang diselenggarakan untuk memberdayakan masyarakat melalui pendidikan kecakapan hidup, pendidikan anak usia dini, pendidikan kepemudaan, pendidikan pemberdayaan perempuan, pendidikan keaksaraan, pendidikan keterampilan dan pelatihan kerja, pendidikan kesetaraan, serta pendidikan lain yang ditujukan untuk mengembangkan kemampuan peserta didik.

Dalam melaksanakan program tersebut dapat melalui lembaga satuan pendidikan nonformal yang telah disebutkan pada pasal 3, bahwa satuan pendidikan nonformal terdiri dari: LKP, Kelompok Belajar, PKBM, Majelis Taklim, dan Satuan PNF Sejenis 
seperti Rumah Pintar, Balai Belajar Bersama, Lembaga Bimbingan Belajar, serta bentuk lain yang berkembang di masyarakat dan ditetapkan oleh Direktur Jenderal Pendidikan Anak Usia Dini, Nonformal, dan Informal.

Sebagai salah satu program pendidikan luar sekolah serta dalam rangka ikut mencerdaskan bangsa serta usaha melestarikan program Pendidikan luar sekolah melalui sebuah program pemberdayaan masyarakat untuk pengembangan gerakan literasi serta pengembangan budaya baca pada masyarakat akan peningkatan pengetahuan dan wawasan yang lebih baik dan berarah pada progres atas kehidupan serta berkepribadian baik pribadi, kelompok maupun dalam bermasyarakat.

TBM dilihat dari fungsinya sebenarnya sama saja dengan perpustakaan-perpustkaan umum, namun bedanya perpustakaan sudah dilengkapi dengan sarana seperti bangunan, koleksi, sarana yang sudah mendukung serta sudah dikelola oleh tenaga yang berasal dari pendidikan yang berpendidikan ilmu perpustakaan sedangkan TBM masih banyak yang belum mempunyai bangunan permanen atau gedung, buku-buku yang belum sesuai serta kurang dan masih dikelola pribadi.

Selain itu, TBM hadir lebih bervariasi dibandingkan dengan perpustakaan. Kita mungkin sudah mengetahui dalam suatu perpustakaan sering diberitahukan peraturanperaturan yang berlaku. Berbeda dengan TBM, TBM adalah lembaga diluat jalaur formal yang di kelola dengan dana swadaya masyarakat dan biasaya tidak diberlakukan peraturan-peraturan seperti di perpustakaan. Kehadiran TBM yang dibuat dari, untuk, dan oleh masyarakat diharapkan dapat mempercepat perkembangan budaya baca masyarakat.

Dengan adanya TBM sebagai sumber belajar masyarakat memliki kedudukan strategis dalam menggali potensi masyarakat. Masyarakat dapat melakukan proses pendidikan nonformal sepanjang hayat melalui fasilitas yang disediakan dan kegiatan yang dibuat oleh TBM. Keberadaan tempat pembelajaran di lingkungan masyarakat diharapkan mampu mendorong dan mempercepat terwujudnya masyarakat belajar (learning society). Yakni masyarakat yang gemar membaca, melek informasi, dan mampu bersaing di era kompetitif sehingga masyarakat terbebas dari kemiskinan, keterbelakangan, dan kebodohan. Kemudian di TBM masyarakat bisa memperoleh pengetahuan dengan membaca koleksi-koleksi yang ada, kemudian mereka juga bisa mempraktekkan ilmu yang mereka peroleh dari bacaan tersebut di TBM disamping tempat untuk membaca juga tempat untuk pengembangan kreatifitas.

Keberadaan TBM di lingkungan masyarakat jika disadari lebih mendalam, tak lain adalah salah satu upaya pemberdayaan masyarakat. Pemberdayaan yang dilakukan oleh TBM merupakan suatu gambaran lain tentang pola-pola pemberdayaan yang lebih produktif yanitu dengan cara membaca koleksi yang ada di TBM, kemudian pembaca bisa mempraktekkan hasil yang diperoleh melalui bacaannya.

Menurut Hodgson (Tarigan, 2013:7) menyebutkan bahwa membaca adalah suatu proses yang dilakukan serta dipergunakan pembaca untuk memperoleh pesan, yang hendak disampaikan oleh penulis melalui media kata-kata atau bahasa tulis. Dengan membaca maka akan memperoleh informasi, dimana informasi diproduksi keseluruh 
dunia melalui media cetak serta elektronik.

Sementara dengan dibuktikannya kemajuan teknologi maka tradisi lisan atau obrolan beralih ke tradisi tulisan dan persebaran naskah tertulis semakin meluas, dengan kita membaca dapat memperoleh dan memperluas ilmu pengetahuan, informasi serta kebudayaan. Selain itu, membaca merupakan salah satu cara untuk mendapatkan informasi dari sesuatu yang ditulis oleh seseorang. Semakin banyak membaca, semakin banyak pula pengetahuan dan wawasan yang kita dapatkan, walaupun terkadang kita dapatkan secara tidak langsung.

\section{B. LANDASAN TEORI DAN METODE PENELITIAN \\ a. Taman Bacaan Masyarakat}

Menurut Peraturan Menteri Pendidikan dan Kebudayaan Nomor 81 Tahun 2013 tentang Pendirian Satuan Pendidikan Nonformal, pasal 1, angka 8 menyatakan bahwa Program Pendidikan Nonformal adalah layanan pendidikan yang diselenggarakan untuk memberdayakan masyarakat melalui pendidikan kecakapan hidup, pendidikan anak usia dini, pendidikan kepemudaan, pendidikan pemberdayaan perempuan, pendidikan keaksaraan, pendidikan keterampilan dan pelatihan kerja, pendidikan kesetaraan, serta pendidikan lain yang ditujukan untuk mengembangkan kemampuan peserta didik.

Menurut Sutarno NS (2008 : 129) Taman Bacaan Masyarakat adalah tempat yang sengaja dibuat pemerintah, perorangan, atau swakelola dan swadaya masyarakat untuk menyediakan bahan bacaan dan menumbuhkan minat baca kepada masyarakat yang berada di sekitar Taman Bacaan Masyarakat (TBM).

Menurut Juknis Program Penguatan Taman Bacaan Masyarakat yang diterbitkan Dirjen PAUDNI bahwa TBM adalah tempat atau wadah yang didirikan dan dikelola baik oleh masyarakat maupun pemerintah dalam rangka penyediaan akses layanan bahan bacaan bagi masyarakat sekitar sebagai salah satu sarana utama dalam perwujudan konsep pembelajaran sepanjang hayat untuk mendukung peningkatan kualitas hidup masyarakat sekitar TBM. Kemendikbud (Andri Yanto, 2016:107-118). Jadi, bisa diartikan Taman Baca Masyarakat adalah sarana atau tempat yang di dalammnya menyediakan bahan bacaan yang dibutuhkan masyarakat secara umum baik anak-anak remaja sampai usia lanjut dan dikelola oleh masyarakat sendiri untuk mewadahi minat baca masyarakat.

Adapun tujuan-tujuan TBM didirikan untuk meningkatkan kemampuan membaca, menumbuhkembangkan serta membangan minat dan kegemaran membaca masyarakat, membantu terwujudkan masyarakat yang mau belajar sepanjang hayat dan terwujudnya masyarakat mandiri. Sedangkan untuk fungsi TBM yaitu sebagai sumber belajar, sebagai sumber pengetahuan dan informasi serta sebagai tempat bermain dan belajar.

\section{b. Pengelolaan}

Menurut Djudju Sudjana (2010 : 17) Pengelolaan atau manajemen adalah kemampuan dan keterampilan khusus untuk melakukan suatu kegiatan baik bersama orang lain atau melalui orang lain dalam mencapai tujuan organisasi. 
Sedangkan menurut Hersey dan Blanchard (Djuju Sudjana, 2010: 17) memberi arti pengelolaan "Manajement as working with and through individuals and groups to accomplish organizational goals" (pengelolaan merupakan kegiatan yang dilakukan bersama dan melalui orang-orang serta kelompok dengan maksud untuk mencapai tujuan-tujuan organisasi).

George R. Terry (J.Smith D.F.M, 2014 : 9) majemen merupakan sebuah kegiatan, pelaksanaanya disebut manajing dan orang yang melakukannya disebut manajer. Dapat disimpulkan bahwa pengelolaan yaitu kegiatan yang dikerjakan bersama-sama agar tercapainya sebuah tujuan-tujuan bersama.

Fungsi manajemen menurut George R Terry (Djudju Sudjana, 2010 : 49), mengemukakan empat fungsi manajemen dengan singkatan POAC yaitu : Planning (perencanaan), Organizing (pengorganisasian), Actuating (pelaksanaan), dan Controling (pengewasan).

\section{c. Membaca dan Minat Membaca}

Dalam pembelajaran Bahasa Indonesia, aspek keterampilan berbahasa menurut Tarigan (2013:1) mencakup empat keterampilan, yaitu keterampilan menyimak, keterampilan berbicara, keterampilan membaca, keterampilan menulis. Menurut (Maimunah Hasan, 2013:311) membaca merupakan hakikat sudah dapat diajarkan pada balita, namun menurut penelitian glen lebih efektif diberikan pada usia empat tahun daripada usia lima tahun. Bahkan, menurutnya, usia tiga tahun lebih mudah daripada empat tahun.

Jelasnya makin kecil makin gampang buat belajar, akan tetapi tantangan untuk mengajarkannya pun harus lebih ekstra sabar. Dan mengajar membaca harus dimulai dengan mengeja, dimulai dengan pengenala huruf kemudian mengenal suku kata, barulah mengenal kata dan akhirnya kalimat. Membaca mempunyai tujuan utama yaitu untuk memperoleh dan mendapatkan informasi dan dapat memahami isi maupun makna dari bacaan tersebut.

Minat membaca merupakan faktor utama dalam meningkatkan kualitas masyarakat. Untuk mengetahui tinggi rendahnya minat membaca masyarakat dilihat dari jumlah buku-buku baru yang diterbitkan oleh setiap produsen buku dan jumlah perpustakaan yang tersedia di masyarakat. Seseorang tidak akan membaca, apalagi memiliki budaya membaca apabila minat membaca di kalangan masyarakat masih rendah dan apabila minat membaca tinggi maka seharusnya ia memiliki kebiasaan membaca. (Sartono, 2001:4)

\section{d. Pendidikan Luar Sekolah}

Menurut Coombs (Djudju Sudjana, 2000 : 21) berpendapat bahwa "Pendidikan nonformal ialah setiap kegiatan terorganisasi dan sistematis, di luar sistem persekolahan yang mapan, dilakukan secara mandiri atau merupakan bagian penting dari kegiatan yang lebih luas, yang sengaja dilakukan untuk melayani peserta didik tertentu di dalam mencapai tujuan belajarnya".

Pendidikan luar sekolah adalah sebuah program pendidikan yang dilaksanakan diluar 
sistem pendidikan persekolah yang berlaku, dilakukan secara sengaja dalam rangka membelajarkan peserta didik yang disesuaikan dengan kebutuhan sehingga diharapkan tercapainya sebuah perubahan. Pendidikan Luar Sekolah bertujuan: (a) membantu warga belajar agar dapat berkembang dari sedini mungkin dan berkelanjutan guna menigkatkan martabat dan mutu kehidupannya; (b) Membina warga belajar agar memiliki pengetahuan, keterampilan, serta mental yang digunakan untuk mengembangkan diri, berkerja mencari nafkah atau melanjutkan ke tingkat dan atau jenjang pendidikan yang lebih tinggi; (c) Memenuhi kebutuhan belajar masyarakat yang dapat dipenuhi dalam jalur pendidikan sekolah.

\section{e. Metode Penelitian}

Metode penelitian menggunakan metode dekriptif dengan pendekatan kualitatif. Menurut Sugiyono, (2014 : 9) metode penelitian yang berlandaskan pada filsafat postpositivisme, digunakan untuk meneliti pada kondisi objek yang alamiah, (sebagai lawannya adalah eksperimen) dimana peneliti adalah sebagiinstrumen kunci, teknik pengumpulan data dilakukan secara triangulasi (gabungan), analisis data bersifat induktif/kualitatif, dan hasil penelitian kualitatif lebih menekankan makna dari pada generalisasi.

Teknik pengumpulan data melalui wawancara dengan penglola TBM Silayung dan pengunjung sejumlah 5 orang sebagai sampel dalam penelitian ini. Lokasi penelitian ini di TBM Silayung Desa Ciburuy Kecamatan Padalarang Kabupaten Bandung Barat.

\section{Hasil dan Pembahasan}

Berdasarkan hasil penelitian di lapangan, berikut ini peneliti akan memaparkan hasil penemuan dilapangan yang sesuai dengan pertanyaan penelitian yaitu 1 . Bagaimana proses pengelolaan TBM Silayung dalam memperkuat budaya membaca? 2. Bagaimana strategi pengelola TBM Silayung dalam memperkuat budaya membaca? 3. Bagaimana respon pembaca tersebut terhadap pengelolaan TBM Silayung?

Pembahasan pertama mengenai bagaimana proses pengelolaan TBM Menurut hasil pengamatan di lapangan dan wawancara dengan para narasumber diperoleh hasil bahwa pendirian TBM Silayung ini berawal dari kepedulian mahasiswa-mahasiswi IKIP Siliwangi Cimahi ketika melaksanakan kegiatan GSSM (KKN-PPL) di Desa Ciburuy dengan dibantu oleh karangtaruna setempat yang memang sangat menginginkan adanya TBM ini.

Sebagaimana hasil wawancara dengan HS, sebagai pengelola TBM Silayung yaitu, “.... TBM ini didirikan bersama mahasiswa IKIP Siliwangi dan masyarakat kampung kami, selain itu juga aparatur pemerintah Desa Ciburuy membatu dalam pendirian TBM Silayung. Karena memang pada saat mahasiswa dengan saya yang dulu selaku karangtaruna melakukan identifikasi kurang lebih selama tiga pekan memperoleh hasil bahwa masyarakat sekitar memperlukan TBM ini sebgai sumber belajar.Sehingga pada akirnya kami mengurus perizinan pendirian ini dimulai dari aparatur sekitar sampai ke Dinas Pendidikan yang sampai saat ini masih kami urus perizinannya. Prasarana yang kami dapatkan saat ini merupakan hasil swadaya masyarakat termasuk tanah yang menjadi tempat ini adalah tanah hibah dari masyarakat." 
Proses pendirian TBM Silayung sudah sesuai dengan tata cara pendirian suatu lembaga, yaitu mulai dari identifikasi kebutuhan masyarakat, dilanjutkan dengan sosialisasi kepada masyarakat sekitar, selanjutnya perizinan mendirikan TBM yang di mulai dari RT, RW, Desa, kecamatan dan dilanjutkan kembali sampai ke dinas pendidikan agar mendapatkan SK. Pengelolaan TBM sudah sesuai dengan teori bagaimana pengelolaan suatu lembaga yaitu mulai dari perencanaan pendirian TBM. Serta sudah mulai melaksanakan program-program di TBM.

Pembahasan mengenai bagaimana startegi pengelola Hasil pengamatan dilapangan bahwa strategi yang dilakukan oleh pengelola dan pengurus TBM dengan metode jemput bola ke masyarakat sekita, memberikan hadiah kepada anak-anak atau pengunjung yang mau datang serta memberikan pilihan program kegiatan yang dibutuhkan serta keinginan mereka pada saat itu. Berikut hasil wawancara dengan $\mathrm{C}$ sebagai pengurus TBM Silayung : “.....Untuk metode yang sudah kami lakukan agar masyarakat dapat tertarik untuk datang ke sini kami melakukan sosialisai ke masyarakat, datang ke rumah-rumah masyarakat yang di utamakan memliki anak usia sekolah, kami promosi di media sosail yang kami selalu kelola selama seminggu sekali. Kami juga memberikan hadiah kepada mereka yang may datang seperti makanan ringan atau apakah yang bisa membuat mereka datang tertarik ke sini, untuk program sendiri kami sesuaikan dengan kebutuhan mereka. Seperti mereka ingin mewarnai, belajar bahasa inggris atau hanya baca-baca buku saja pun ada."

Pembahasan selanjunya mengenai respon pembaca tersebut terhadap pengelolaan TBM Silayung Hasil penelitian menunjukkan bahwa respon dari pengunjung TBM sangat bangus dan mereka sangat antusias untuk datang kesana. Salah satu pengunjung yang di wawancara oleh peneliti yaitu W sebagai berikut, "....Saya senang datang ke TBM ini, banyak teman dan juga bisa baca-baca buku atau mewarnai. Saya paling senang berkunjung untuk mewarnai."

Program yang dijalankan untuk menarik respon pengunjung memang sudah baik, akan tetapi untuk memperkuat minat membaca dikalangan masyarakat sesuai dengan peran TBM yaitu memberikan sarana membaca, diskusi, bedah buku, menulis, dan semua jenis kegiatan lainnya yang dapat melengkapi bahan bacaan masyarakat. TBM Silayung menjalankan perannya dimasyarakat Desa Ciburuy sebagai sarana dan jantung pendidikan masyarakat desa ciburuy untuk memperkuat minta baca masyarakat sekitar. Selain itu, TBM Silayung seharusnya memberikan program-program kreatif yaitu TBM yang diancang untuk memenuhi kebutuhan kreasi dan rekreasi.

Kreasi disini TBM bukan hanya menyediakan buku-buku untuk bahan bacaan masyarakat, akan tetapi dapat menciptakan aktivitas yang melibatkan partisipasi pengunjung TBM. Pengunjung TBM belajar bersama dengan pengelola TBM dalam membedah informasi yang telah dibaca, agar informasi yang didapat pengunjung yang membaca bukan hanya teori tetapi juga ruang belajar menerjamahkan buku.

Selain berperan sebagai TBM Kreatif TBM Silayung juga bisa berperan sebagai TBM rekreasi yaitu TBM ynag mesti dapat meninggalkan kesan kaku, suram, asing atau bahkan sunyi. Melalui program TBM Silayung yaitu berupa kegiatan membaca di alam terbuka agar pembaca semakin bersemangat, senang, tenang dan bahagia untuk 
berkunjung ke TBM Silayung. Program-program kreatif harus dijalankan agar TBM bisa berperan sebagaimana mestinya, yaitu sebagai jantung informasi di masyarakat. Pengembangan pendidikan yang dilaksanakan pada satuan pendidikan masyarakat, termasuk Taman Bacaan masyarakat adalah upaya dalam membangun karakter yang diharapkan dapat mendorong peningkatan kapasitas masyarakat dalam berbagai bidang, termasuk untuk mengembangkan dan memanfaatkan modal sosial yang tersedia di lingkungan sekitar, inilah yang menjadi dasar utama pemberdayaan, yaitu modal sosial (Mulyono, 2018).

\section{KESIMPULAN}

Taman Baca Masyarakat adalah sarana atau tempat yang di dalammnya menyediakan bahan bacaan yang dibutuhkan masyarakat secara umum baik anak-anak remaja sampai usia lanjut dan dikelola oleh masyarakat untuk mewadahi minat baca masyarakat. Pada kenyataannya minat membaca dikalangan masyarakat masih rendah dan perlu ditingkatkan kembali. Melalui TBM Silayung diharapkan program untuk miningkatkan minta baca masyarakat dapat terwujud dengan prorgam-program yang menarik.

\section{DAFTAR PUSTAKA}

George R terry. (2014). Prinsip Prinsip Manajemen. Jakarta : Bumi Aksara

Mulyono, D. 2018. THE STRATEGY OF MANAGERS IN MOVING BUSINESS LEARNING GROUP PROGRAM IN PKBM SRIKANDI CIMAHI CITY. Journal of Educational Experts (JEE) Vol. 1 (1), 41-50.

Sugiono. (2014). Metode Penelitian Kuantitatif Kualitatif dan R\&D. Bandung: Alfabeta Sudjana, Dj. (2010). Majemen Program Pendidikan Untuk Pendidikan Luar Sekolah dan Pengembangan Sumber Daya Manusia. Bandung : Falah Production

Sudjana, Dj. (2010). Pendidikan Non Formal Wawasan Sejarah Perkembangan Filsafat Teori Pendukung Asas. Bandung : Falah Production

Tarigan, H. (2013). Membaca Sebagai Suatu Keterampilan Berbahasa. Bandung : Angkasa.

Kementrian Pendidikan Dan Kebudayaan. (2013). Petunjuk Teknis TBM Rintisan. [online]. Tersedia http://repositori.perpustakaan.kemdikbud.go.id/1233/1/Petunjuk\%20Teknis\%2 0TBM\%20Rintisan.pdf diakses pada tanggal 05 April 2017.

Ludfia. (2015). Upaya pembinaan minat baca di taman bacaan masyarakat. [Online]. Tersedia http://repository.uinjkt.ac.id/dspace/bitstream/123456789/29858/1/11100250 00062.pdf diakses pada tanggal 05 April 2017.

Andri, Y. et.all. (2016). Model Aktivitas Gerakan Literasi Berbasis Komunitas Di Sudut Baca Soreang. [Online]. Tersedia di journal.unpad.ac.id/jkip/article/view/11629/5457. diakses pada tanggal 10 Februari 2018.

Tribunnews.com. (2017). Memprihatikan Ternyata Minat Baca Indonesia Duduki Peringkat 60 Dari 61 Negara. [Online]. Tersedia di http://www.tribunnews.com/regional/2017/05/15/memprihatinkan-ternyataminat-baca-indonesia-duduki-peringkat-60-dari-61-negara. Diakses pada tanggal 14 November 2107. 
Pikiran Rakyat. (2013). Kunjungan Ke Peroustakaan Masih Sangat Rendah. [Online]. Tersedia di http://www.pikiran-rakyat.com/jawabarat/2013/10/21/255680/kujungan-ke-perpustakaan-masih-sangat-rendah diakses pada tanggal 14 Desember 2017. 